\title{
Metal bioaccumulation in fish Labeo rohita exposed to effluent generated during metals extraction from polymetallic sea nodules
}

\author{
H. Vaseem · T. K. Banerjee
}

Received: 14 April 2012/Revised: 14 June 2013/Accepted: 29 September 2013/Published online: 25 October 2013

(C) Islamic Azad University (IAU) 2013

\begin{abstract}
The aim of this study was to investigate the potential impact of effluent released during metals extraction from polymetallic sea nodules at the Pilot Plant at National Metallurgical Laboratory, India, by analysing different metal ( $\mathrm{Mn}, \mathrm{Cu}, \mathrm{Zn}, \mathrm{Fe}, \mathrm{Pb}$ and $\mathrm{Cr}$ ) concentrations in six tissues (skin, muscles, gills, liver, kidney and brain) of the fish Labeo rohita. Of the six analysed tissues of seanodule-effluent-exposed fish, liver accumulated highest concentration of most of the metals (2.91-287.36 $\mathrm{mg} \mathrm{kg}^{-1}$ ) while muscles $\left(2.1-81.14 \mathrm{mg} \mathrm{kg}^{-1}\right)$ lowest. While the concentration of $\mathrm{Fe}$ was maximum $\left(60.41-218.7 \mathrm{mg} \mathrm{kg}^{-1}\right.$ ) in all the tissue systems (except muscles and liver), $\mathrm{Pb}$ was minimum $\left(0.8-2.91 \mathrm{mg} \mathrm{kg}^{-1}\right)$. Accumulation of most of the metals in all the tissues was above the safe limits as recommended by Food and Agricultural Organisation that indicate metal's potential hazardous impact on the fish. High bioaccumulation factors for these metals in the different tissues revealed that metals were extensively bio accumulated and bio concentrated. The time-dependent variation in metal pollution index illustrated increase in gross metal load $(p<0.05)$ in different tissue components with increase in exposure period. In conclusion, the sea nodule effluent was found to cause adverse health impact on the fish which in turn might also affect the human health when consumed.
\end{abstract}

Keywords Atomic absorption spectrophotometry Heavy metal accumulation · Fish tissues - Health hazard

H. Vaseem · T. K. Banerjee $(\bowtie)$

Department of Zoology, Banaras Hindu University (BHU),

Varanasi 221005, India

e-mail: tkbzool50@yahoo.co.in

\section{Introduction}

As the land-based resources of metals are depleting very fast, metallurgists have moved forward for their alternative sources of extraction. Ocean covering the $71 \%$ of the earth's surface had always fascinated the scientists that made them to explore it, and metallurgists have found polymetallic sea nodules (PMN) as major source of a large number of important metals. PMNs are small, dark brown coloured balls, slightly flattened, measuring $5-10 \mathrm{~cm}$ in diameter. These nodules lay on the sea bed at 4,000-6,000 m deep. PMNs are made up of metal as well as nonmetal components. These nodules contain manganese, iron, aluminium, nickel, copper, cobalt and titanium as their major constituents along with some minor components such as sodium, magnesium, silicon, zinc, oxygen and hydrogen. Scientists at the National Metallurgical Laboratory, Council of Scientific and Industrial Research, Jamshedpur, India, have developed an indigenous technique to recover the metals from PMN. These nodules are passed through metallurgical processes including reduction, ammonia leaching, solvent extraction, electro winning and smelting (Jana et al. 1999; Kumar et al. 1990; Agarwal and Goodrich 2008; Biswas et al. 2009). During these processes, a large amount of highly contaminated effluent is generated which also retains substantial amount of the precious otherwise toxic metals. While analysing the physicochemical nature of the sea nodule effluent, Vaseem and Banerjee (2012) recently found that several toxic metals are present above their permissible limits in this effluent (EPA 2002). These highly toxic metals are the main cause of environmental pollution and are of concern due to their toxicity, persistence, bioaccumulation and biomagnifications into the food chain (Storelli 2008; Groth 2010; Mendil et al. 2010). Among animal 
species, fishes are the inhabitants that cannot escape from the detrimental effects of the water-borne contaminants. Hence, fishes are often used as effective bioindicator for pollution monitoring (Olaifa et al. 2004; Clarkson 1998). Heavy metals cannot be destroyed through biological degradation and have the ability to accumulate in the aquatic organisms such as fish which make these toxicants deleterious to the aquatic environment and consequently to the humans who depend upon fish as a source of food. Hence, the accumulation of metals in the aquatic animals can be used as a reasonable measurement for public and animals health standard. The pattern of bioaccumulation of metals in different tissues or organ systems of animals varies according to their metabolic activities. The total metal load or gross metal accumulation in each tissue component or organ system has been illustrated by calculating metal pollution index (MPI). L. rohita, a major Indian carp, has been selected to know the detrimental effect of the sea nodule effluent on the aquatic organisms because of its regular use as important source of animal proteins.

The extraction of metals from PMN is an emerging technique that also needs sincere consideration to define the toxic impact of effluent released during PMN processing. The present study conducted from April 2011 in the laboratory at Banaras Hindu University is an effort in this direction to advise the metallurgist to take utmost care to reduce the toxic stress of this highly contaminated effluent before their disposal. The toxicity of the effluent was analysed by illustrating accumulation of the toxic metals, calculating bioaccumulation factor (BAF) and MPI of different organ systems (skin, muscles, gills, liver, kidney and brain) of the carp L. rohita exposed to sea nodule effluent for 20 days.

\section{Materials and methods}

\section{Experimental design}

Irrespective of sex, healthy specimens of the Indian major carp L. rohita were collected in the month of March 2011 from the hatchery situated at Banaras Hindu University, Varanasi, India. The fish were acclimated to the laboratory conditions for 1 month in plastic tanks containing wellaerated and dechlorinated water at $24 \pm 2{ }^{\circ} \mathrm{C}$ under natural photoperiod. During this period, fish were fed ad libitum with commercial fish pellets ( $40 \%$ of protein). The water quality parameters were kept nearly constant: dissolved oxygen (7.0-7.5 $\left.\mathrm{mg} \mathrm{l}^{-1}\right)$, $\mathrm{pH}$ (7.1-7.4), conductivity $\left(125-130 \mu \mathrm{S} \mathrm{cm}^{-1}\right)$, alkalinity $\left(35-43 \mathrm{mg} \mathrm{l}^{-1}\right.$ as $\mathrm{CaCO}_{3}$ ) and total hardness (39-50 $\mathrm{mg} \mathrm{l}^{-1}$ as $\mathrm{CaCO}_{3}$ ).
The effluent generated from the pilot plant at NML (CSIR), Jamshedpur, India, during recovery of metals from polymetallic sea nodule was brought to the laboratory at Banaras Hindu University, in large plastic containers having no contamination.

Batches of 20 fish (weight $28-30 \mathrm{~g}$, length $11-12 \mathrm{~cm}$ ) were exposed to the 501 of the effluent (BOD: $182 \pm 3 \mathrm{mg} \mathrm{l}^{-1}, \mathrm{pH}: 5.2$, Sodium: $130.26 \pm 1.96 \mathrm{mg} \mathrm{l}^{-1}$, Potassium: $\quad 3.42 \pm 0.07 \mathrm{mg} \mathrm{l}^{-1}$, Sulphate: $2,300 \pm$ $4.515 \mathrm{mg} \mathrm{l}^{-1}$, Carbonate: $296 \pm 2.2 \mathrm{mg} \mathrm{l}^{-1}$ ) (control fish retained in the laboratory water) for maximum period of 20 days (beyond which the fish died) with periodic renewal of the effluent. Eight fish each from experimental as well as control aquaria were cold anesthetized and killed after 10 and 20 days of exposure. Entire brain, liver, kidney, gills, small fragments of muscle and skin were dissected out for further processing. Three replicates of each experimental set were run simultaneously.

Heavy metal analysis

Six organ systems (muscle, gills, liver, kidneys, brain and skin) of exposed as well as untreated (control) fish were subjected to analyses of metal accumulation. One gram of each of the tissue samples was dried in petridishes in an oven at $120{ }^{\circ} \mathrm{C}$ till there was no further weight loss. Subsequently, they were put into digestion flasks containing a mixture of nitric acid and perchloric acid $(4: 1 \mathrm{v} / \mathrm{v})$. The digestion flasks were further heated on a hot plate at $120{ }^{\circ} \mathrm{C}$ till the materials got dissolved. Later double distilled water was added to the digestion samples in volumetric flask to make the volume up to $25 \mathrm{ml}$. Amount of metals were analysed using atomic absorption spectrophotometer (AAS, Perkin Elmer). Detection limits of AAS for metals in $\mathrm{mg} \mathrm{kg}^{-1}$ were 0.1 for $\mathrm{Fe}, 0.1$ for $\mathrm{Mn}, 0.1$ for $\mathrm{Zn}, 0.01$ for $\mathrm{Cu}, 0.01$ for $\mathrm{Pb}, 0.02$ for $\mathrm{Cr}$ and 0.01 for $\mathrm{Ni}$. The concentration of the metals in tissues has been given in $\mathrm{mg} \mathrm{kg}{ }^{-1}$ dry weight of tissue.

\section{Bioaccumulation factor}

The bioaccumulation factor (BAF) is the ratio between the accumulated concentration of a given pollutant in any organ and its dissolved concentration in water (Authman and Abbas 2007). It was calculated using the following equation (Eq. 1):

Bioaccumulation factor (BAF)

$=\frac{\text { Pollutantconcentrationinfishorgan }}{\text { Pollutant concentration in water }}$ 
Metal pollution index

Metal pollution index (MPI) was applied to compare the total metal accumulation level in various tissues of the fish. The MPI values were calculated using the equation proposed by Usero et al. (1997) (Eq. 2):

$\mathrm{MPI}=\left(C_{\mathrm{f} 1} \times C_{\mathrm{f} 2} \times \ldots C_{\mathrm{f} n}\right)^{1 / n}$

where, $C_{\mathrm{fn}}$ is the concentration for the metal $n$ in the sample.

\section{Statistical analysis}

For statistical analyses, one-way analysis of variance (ANOVA) was performed to determine significance of differences $(p<0.05)$ between the pairs of means. Duncan's Multiple Range Test was also carried out to find out whether any mean is significantly different $(p<0.05)$ from others. The heavy metal concentrations in fish

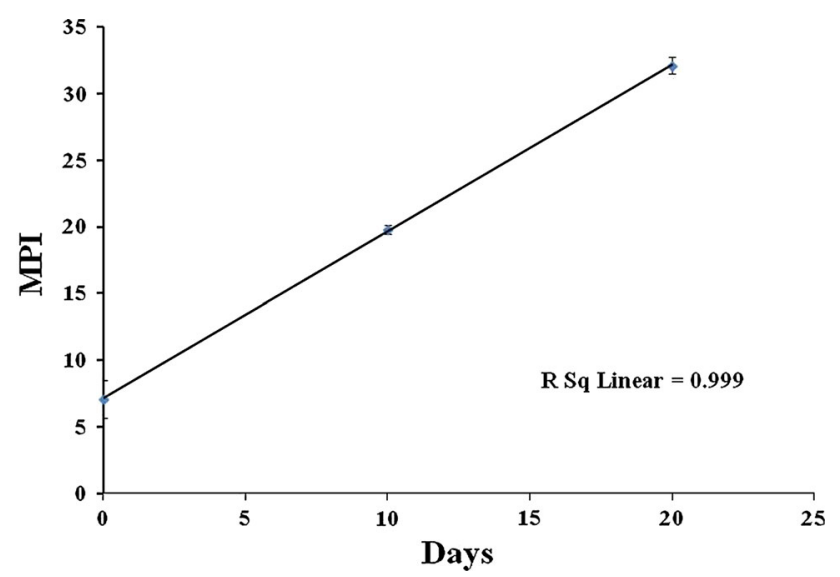

Fig. 1 Time-dependent variation in MPI of skin tissue

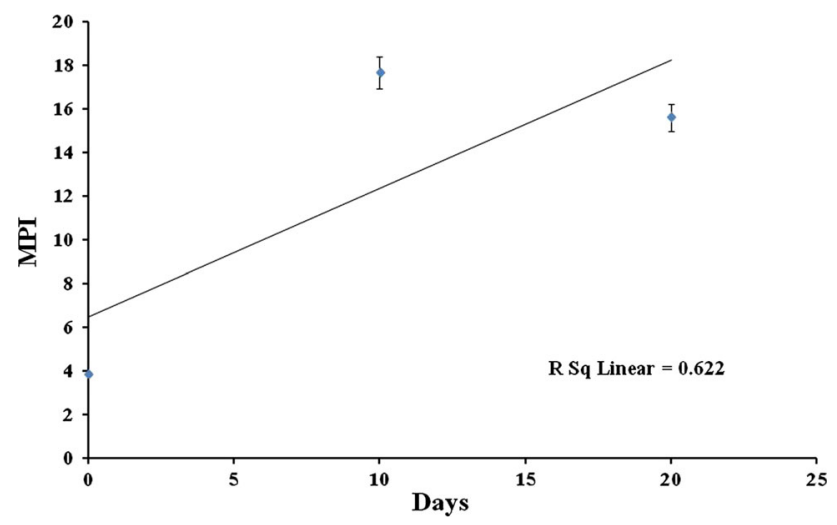

Fig. 2 Time-dependent variation in MPI of muscle tissue

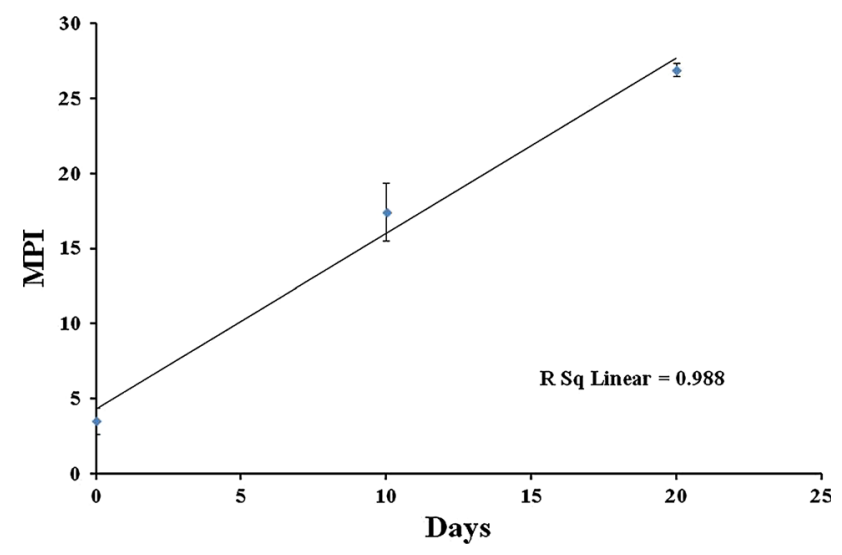

Fig. 3 Time-dependent variation in MPI of gill tissue

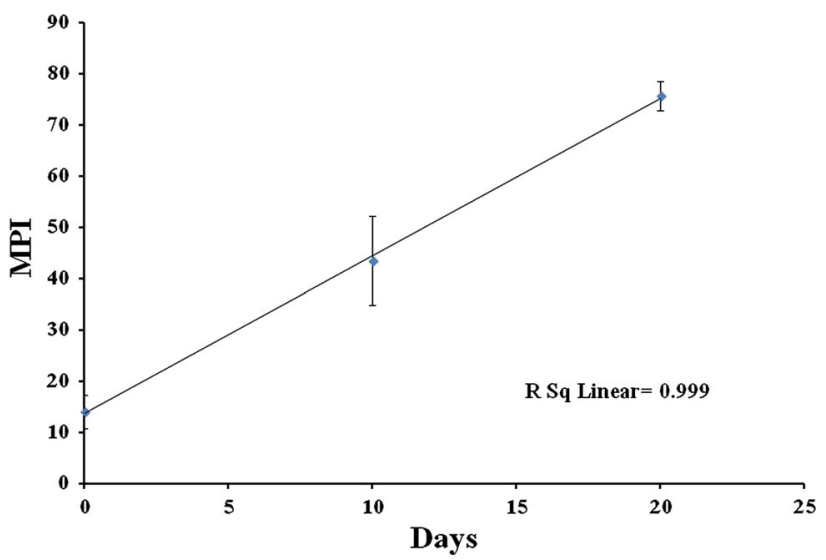

Fig. 4 Time-dependent variation in MPI of liver tissue

samples were expressed as mean \pm SD. Regression analysis for MPI and exposure period were performed by using Microsoft Office Excel 2007. In case of Figs. (1, 2, 3, 4, 5, and 6) for MPI control values has been taken as 0 day.

\section{Results and discussion}

The presence of a large number of toxic metals much above the safe limits in the sea nodule effluent made it highly toxic (Vaseem and Banerjee 2012). The same authors (Vaseem and Banerjee 2013) also observed marked deterioration in the biochemical constitution of six tissues of the fish exposed to PMN effluent.

Exposure to this effluent also caused bioaccumulation of metals in different organ systems of the fish. The data related to metal concentrations $(\mathrm{Mn}, \mathrm{Cu}, \mathrm{Zn}, \mathrm{Fe}, \mathrm{Pb}, \mathrm{Cr}$ and $\mathrm{Ni}$ ) in different tissue components of the control and 


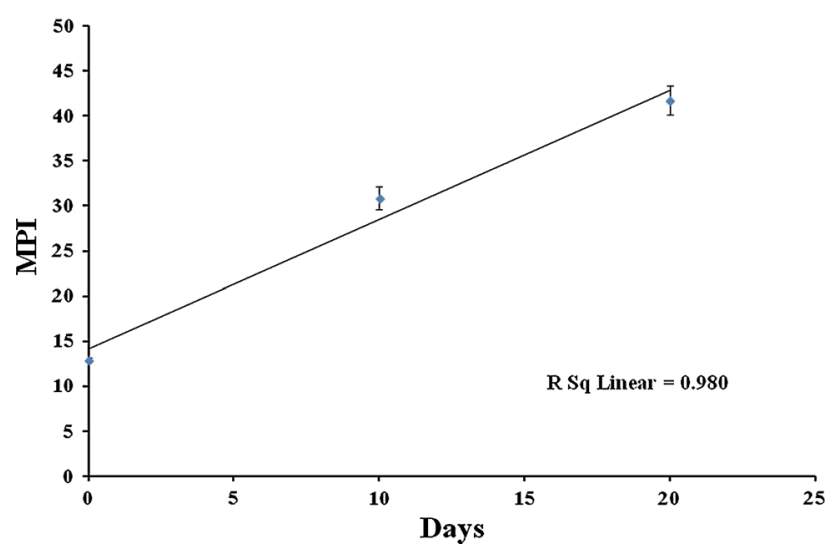

Fig. 5 Time-dependent variation in MPI of kidney tissue

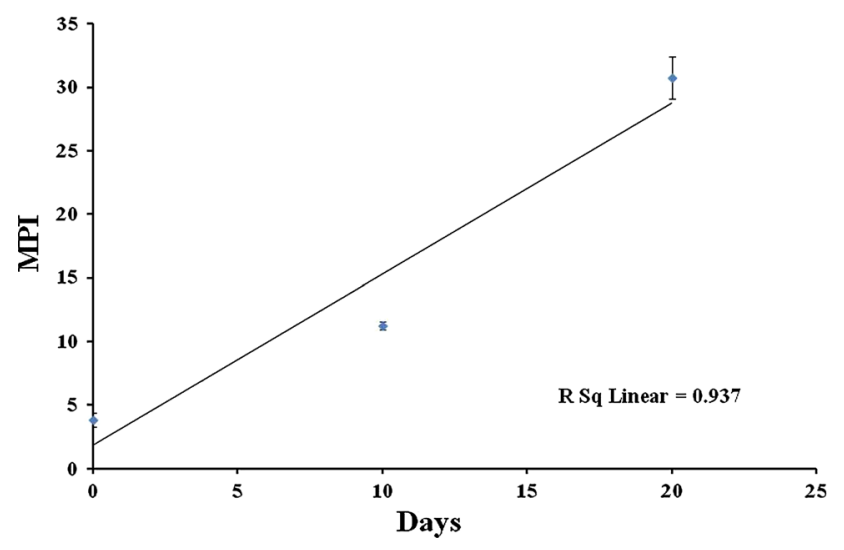

Fig. 6 Time-dependent variation in MPI of brain tissue

exposed fish have been summarised in Table 1. Of the different metals analysed, the concentration of $\mathrm{Ni}$ was below detectable levels in control as well as all the exposed tissues. $\mathrm{Pb}$ and $\mathrm{Cr}$ were also below the detectable level in all these tissues of the control as well as 10-day-exposed fish. In the 20-day-exposed fish, however, $\mathrm{Pb}$ was not detected in the skin and brain. $\mathrm{Cr}$ was present in all the 20-day-exposed tissues (Table 1). Following exposure, the liver accumulated highest amount of the metals, while muscles showed least deposition excepting $\mathrm{Cr}$ whose concentration was lowest in the skin. Trend of concentration of most of the metals present in tissues of exposed fish was liver $>$ kidney $>$ gills $>$ brain $>$ skin $>$ muscles.

Highest accumulation of metals in the liver tissue might be because it is the main site for synthesis of various proteins and other molecules which have high affinities for metals (Fernandes et al. 2008). Also liver being the main site of detoxification of various contaminants, different xenobiotics including metals are transported to this organ from different sites of absorption (Kargin and Erdem 1991). After liver, kidneys became the next important organ of bioaccumulation of metals from the effluent because of their excretory function.

Gills have large surface areas and remain always in direct contact with the aquatic environment; hence, chances of bioaccumulation of metals in the gills is also very high. Further, the barrier distance between the blood in the gills and ambient toxicants is very narrow causing easy movement of the metals into the gills. The other reason for increased metal accumulation in the gills is perhaps due to the increased density of chloride cells whose number increases in contaminated waters because of their role in picking up of anions including metals ions (Mazon et al. 1999, 2002; Costa and Fernandez 2002). The SH groups of glycoproteins of the slime of the fish gills are known to bind with metals causing increased metal concentration in the gills. Sloughing of the mucus from the gill's surface is not very extensive; hence, the concentration of metals in the gills continues to remain elevated. Further, the slime often remains trapped between neighbouring gill lamellae causing retention of the metals leading to their elevated concentration.

The concentration of different metal accumulation in the muscle was least perhaps due to its compact nature and structural configuration. The other reason might perhaps be due to less extensive blood circulation in the muscles than other vital tissues such as liver, kidneys and gills. Also muscle is a less metabolically active tissue (Adhikari et al. 2009; Wagner and Boman 2003; Radhakrishnan 2010). Even though the skin is a boundary tissue, the accumulation of metals is not so high as noticed in the gills, perhaps due to continuous elaboration and sloughing of slime from the body surface (Singh and Banerjee 2008) causing loss of metals bound with $-\mathrm{SH}$ groups of the slime. A difference in concentration of trace metals in various fish organs has also been indicated by the study of Vinodhini and Narayanan (2008).

In all the tissue systems, accumulation of $\mathrm{Fe}$ was maximum and $\mathrm{Pb}$ was minimum after 20 days (Table 1). Statistical analysis revealed that there were significant differences in metal concentration in 10- and 20-dayexposed fish (Table 1). However, concentration of Fe did not show significant alterations in the muscles of 10 - and 20-day-exposed fish.

Survey of Table 2 revealed that concentration of $\mathrm{Fe}, \mathrm{Cr}$ and $\mathrm{Cu}$ in all the tissues (except muscles) were above the safe limits (FAO 1983). However, Zn was above the permissible limits (FAO 1983) in most of the tissues excepting 


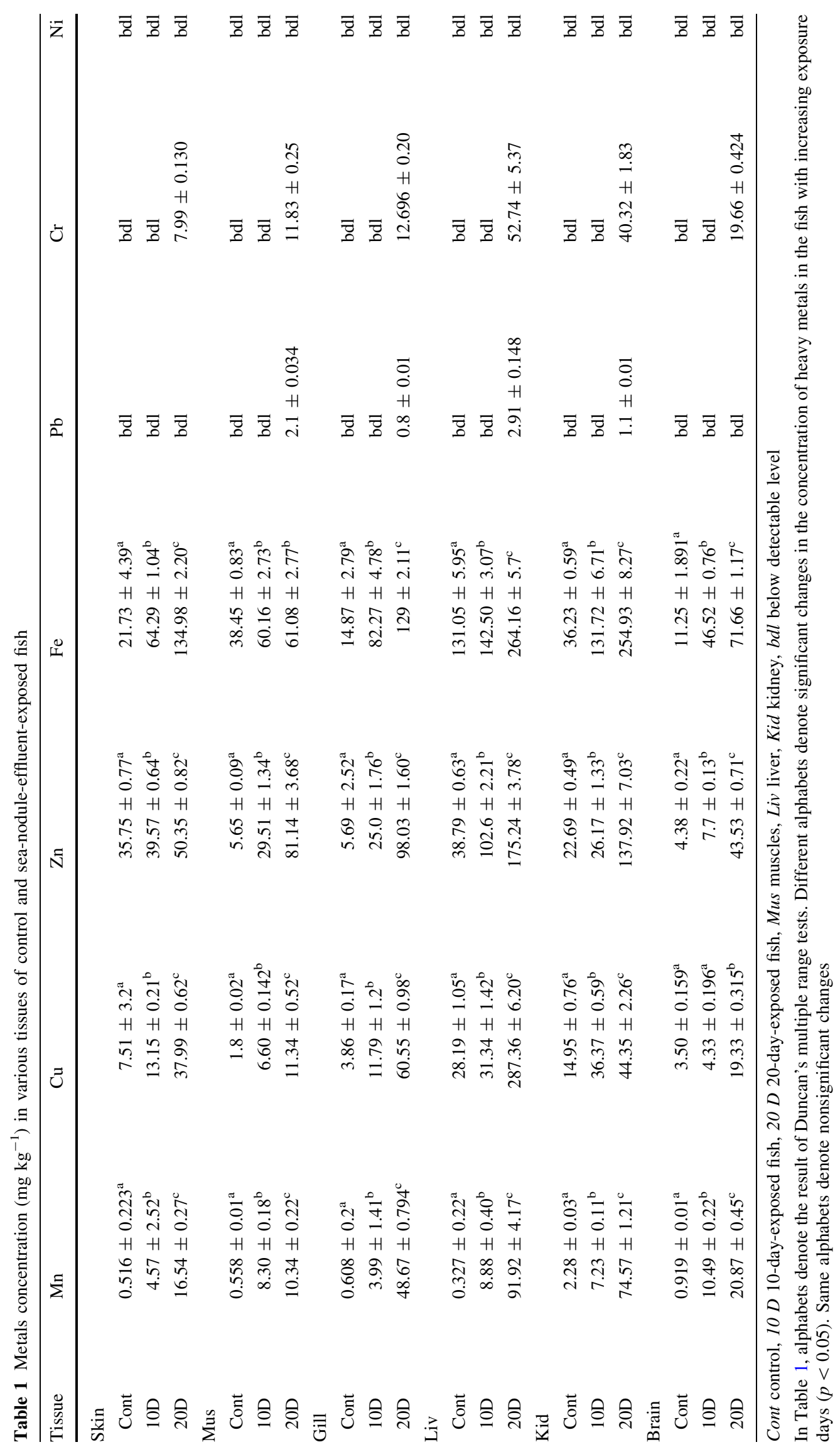


Table 2 Metals absorbed $\left(\mathrm{mg} \mathrm{kg}^{-1}\right)$ in different tissues of fish exposed to sea nodule effluent after 20 days

*FAO (1983) Food and agricultural organisation, $n l^{\neq}$ no limit was suggested by the concerned authority body, \# not accumulated

Table 3 Bioaccumulation factor in different organ systems of 20-day-exposed fish

\begin{tabular}{lcccccc}
\hline Tissue & $\mathrm{Mn}$ & $\mathrm{Cu}$ & $\mathrm{Zn}$ & $\mathrm{Fe}$ & $\mathrm{Pb}$ & $\mathrm{Cr}$ \\
\hline Skin & 15.722 & 30.473 & 14.597 & 113.25 & $-^{\#}$ & 7.992 \\
Muscles & 9.791 & 9.544 & 75.49 & 22.625 & 2.1 & 11.832 \\
Gills & 48.062 & 56.688 & 92.335 & 114.488 & 0.8 & 12.696 \\
Liver & 91.639 & 259.17 & 136.451 & 133.11 & 2.913 & 52.736 \\
Kidney & 72.286 & 29.409 & 115.229 & 218.696 & 1.1 & 40.32 \\
Brain & 19.951 & 15.833 & 39.148 & 60.41 & - & 19.66 \\
FAO* (1983) & $\mathrm{nl}^{\neq}$ & 10 & 50 & 5.6 & 1.5 & 1 \\
\hline
\end{tabular}

\begin{tabular}{lcrrrrl}
\hline Tissue & $\mathrm{Mn}$ & $\mathrm{Cu}$ & $\mathrm{Zn}$ & $\mathrm{Fe}$ & $\mathrm{Pb}$ & $\mathrm{Cr}$ \\
\hline Skin & 3.335 & 26.530 & 61.706 & 177.139 & - & 114.171 \\
Muscles & 2.088 & 7.922 & 99.436 & 80.157 & 3.206 & 169.028 \\
Gills & 9.818 & 42.284 & 120.134 & 169.763 & 1.221 & 181.371 \\
Liver & 18.544 & 200.670 & 214.759 & 346.667 & 4.447 & 753.371 \\
Kidney & 15.04 & 30.976 & 169.02 & 334.553 & 1.679 & 576 \\
Brain & 4.21 & 13.499 & 53.346 & 94.042 & - & 280.857 \\
\hline
\end{tabular}

skin and brain. Leaving apart the gills and kidney, $\mathrm{Pb}$ was above its permissible limits (FAO 1983) in all the tissues. No permissible limit has been set by FAO (1983) for Mn accumulation. Hence, from Table 2, it is clear that most of the metal accumulations in the different tissue systems of the exposed fish were above their permissible limits (FAO 1983). Even though metals like $\mathrm{Zn}, \mathrm{Cu}$ and $\mathrm{Mn}$ act as cofactor in several enzyme activities and that $\mathrm{Fe}$ is directly involved with haemoglobin formation in the blood tissues, their presence in excessive concentration might be toxic to the fish (Zyadah and Abdel-Bakey 2000; Ikem et al. 2003). $\mathrm{Pb}$ is also a toxic element and has no known biological function and shows its negative health effect on aquatic biota and humans (Shahtaheri et al. 2007; Gulser and Erdogan 2008). Chromium is considered as essential trace elements. As it is involved in insulin function and lipid metabolism, it is of great importance, but its higher concentration may cause deleterious effect on the health. Even though our knowledge on the toxic impact of different metals in the human subjects is vast, very little information is available on the deleterious effects of PMN effluent on mammals including human beings. The cumulative and synergistic toxic effects of various metals in different organ systems further aggravate the pathological effect of the effluent on the fish. Most of the metals were found to be above their permissible limits in muscles (edible part) of the exposed fish; hence, these fishes are not suitable for human consumption because consumption of the aquatic food enriched with toxic metals may cause serious health hazard.

To understand the status of bioaccumulation of metals by different organ systems following prolonged exposure of 20 days, the BAF values for these metals in the examined tissue were calculated (Table 3). The highest value of BAF was noticed in the liver for every metal type. Muscles and skin had least BAF values. Amongst the metals studied, Fe showed highest $\mathrm{BAF}$ value and $\mathrm{Pb}$ lowest. The present finding noticed that concentrations of most of the metals in tissues were higher than those of the effluent (Table 3 ) perhaps due to their bioconcentration. It is already reported that aquatic organisms accumulate metals to concentrations many times higher than present in the water (Olaifa et al. 2004). While studying the trace metal concentration in the water, sediment and fish tissues from the lake Tanganyik, Chale (2002) also noticed that concentration of metals in the fish tissues were always higher than that of water. The bioaccumulation factors (BAF) of all the metals in different organs in the present study were too high in relation to their highest value of 1.00 which is the nontoxic limit for a metal. The higher BAF values observed for all the metals were due to their bioaccumulation and bioconcentration in the fish tissues. Iron showed the maximum value of BAF amongst all the analysed tissues except muscle due to their maximum bioaccumulation amongst all the metals. This might perhaps be due to its contribution in composition of a large number of tissue components. Amongst the various tissue components examined, highest value of BAF for liver indicated its role of concentrating metals which is several times higher than their concentration in water. It is perhaps due to trapping of these metals in the metallothionein proteins which were also highest in the liver (Al-Yousuf et al. 2000; Ikem et al. 2003; Kent 1998).

The grossly altered concentrations of the various metals in different tissues in relation to increased period of 
exposure have been properly illustrated in the Figs. 1, 2, 3, 4, 5, and 6 as regression analysis. Figures 1, 2, 3, 4, 5, and 6 showed the time-dependent variation in metal pollution index for skin, muscle, gills, liver, kidney and brain having $R^{2}$ 0.999, 0.622, 0.988, 0.999, 0.980, and 0.937, respectively, indicating the fact that with increased exposure period, concentration of metals increased in all the tissues examined. Due to meagre deposition of metals, the linear relationship in muscle was not properly depicted.

\section{Conclusion}

Fish exposed to sea nodule effluent showed significant bioaccumulation of different metals, most of which were above their permissible limits. MPI values for different organ systems showed linear dependency with the exposure period excepting muscles. Finally, it was found that the sea nodule effluent is very toxic and has negative health impact on the fish. Discharge of this toxic effluent in neighbouring water bodies should be restricted; otherwise, accumulation of different metals in the fish may make them unsuitable for human consumption posing the danger of bioconcentration of the metals at higher tropic levels.

Acknowledgments This work was supported by the Department of Ocean Development, Government of India (Project No. 25/232). The senior author thanks University Grant Commission, Government of India for providing her a Senior Research Fellowship.

\section{References}

Adhikari S, Ghosh L, Giri BS, Ayyappan S (2009) Distribution of metals in the food web of fish ponds of Kolleru lake India. Ecotoxicol Environ Saf 72:1242-1248

Agarwal HP, Goodrich JD (2008) Extraction of copper, nickel, and cobalt from Indian Ocean polymetallic nodules. Can J Chem Eng 81:303-306

Al-Yousuf MH, El-Shahawi MS, Al-Ghais SM (2000) Trace metals in liver, skin and muscle of Lethrinus lentjan fish species in relation to body length and sex. Sci Total Environ 256:87-94

Authman M, Abbas H (2007) Accumulation and distribution of copper and zinc in both water and some vital tissues of two fish species (Tilapia zilli and Mugil cephales) of lake quran, Fayoum Province. Egypt Pak J Biol Sci 10:2106-2122

Biswas A, Chakraborti N, Sen PK (2009) Multiobjective optimization of manganese recovery from sea nodules using genetic algorithms. Mater Manuf Process 24:22-30

Chale FM (2002) Trace metal concentrations in water, sediments and fish tissue, Lake Tanganyika. Sci Total Environ 299:115-121

Clarkson TW (1998) Human toxicology of mercury. J Trace Elem Exp Med 11:303-317

Costa OTF, Fernandez MN (2002) Chloride cell changes induced by nitrite exposure in an Amazonian fish species. In: Kennedy C, Kolok A, MacKinlay D (eds) Aquatic toxicology: mechanism and consequences. International congress of fish biology, Canada pp 51-61
Environmental Protection Act (2002) Standards for effluent discharge regulations. General notice No. 44 of 2003, http://faolex.fao.org/ docs/texts/mat52519.doc

Fernandes D, Bebianno MJ, Porte C (2008) Hepatic levels of metal and metallothioneins in two commercial fish species of the Northern Iberian shelf. Sci Total Environ 39:159-167

Food and Agricultural Organisation (1983) Compilation of legal limits for hazardous substances in fish and fishery products. FAO: fishery circular, no. 464,5

Groth E (2010) Ranking the contributions of commercial fish and shellfish varieties to mercury exposure in the United States: implication for risk communication. Environ Res 110:226-236

Gulser F, Erdogan E (2008) The effects of heavy metal pollution on enzyme activities and basal soil respiration of roadside soils. Environ Monitor Assess 145:127-133

Ikem A, Egiebor NO, Nyavor K (2003) Trace elements in water, fish and sediments from Tuskegee lake, Southeastern USA. Water Air Soil poll 149:51-75

Jana RK, Pandey BD, Premchand (1999) Ammonial leaching of roast reduced deep-sea manganese nodules. Hydrometallurgy 53:45-56

Kargin F, Erdem C (1991) Accumulation of copper in liver, spleen, stomach, intestine, gill and muscle of Cyprinus carpio. Doga Tr J Zool 15:306-314

Kent C (1998) Basic toxicology. Wiley, New York, pp 1-402

Kumar V, Pandey BD, Akerkar DD (1990) Electrowinning of nickel in the processing of polymetallic sea nodules. Hydrometallurgy 24:189-201

Mazon AF, Cerqueria CCC, Monteiro EAS, Fernandez MN (1999) Acute copper in fresh water fish: morphological and physiological effects. In: Val AL, Almeida-val VMF (eds) Biology of tropical fishes: INPA. Manaus, Brazil, pp 261-275

Mazon AF, Monteiro EAS, Pinheiro GHD, Fernandez MN (2002) Hematological and physiological changes induced by short-term exposure to copper in the freshwater fish, Prochilodus scrofa. Braz J Biol 62:621-631

Mendil D, Demirci Z, Tuzen M, Soylak M (2010) Seasonal investigation of trace element contents in commercially valuable fish species from the Black sea, Turkey. Food Chem Toxicol 48:865-870

Olaifa FE, Olaifa AK, Adelaja AA, Owolabi AG (2004) Heavy metal contamination of Clarias gariepinus from a lake and fish farm in Ibadan, Nigeria. Afr J Biomed Res 7:145-148

Radhakrishnan MV (2010) Accumulation of trace metals in tissues of Heteropneustes fossilis collected from Chaliyar river, Kerala, India. World J Fish Mar Sci 2:303-306

Shahtaheri SJ, Khadem M, Golbabaei F, Rahimi-Froushan A, Ganjali MR, Norouzi P (2007) Solid phase extraction for evaluation of occupational exposure to $\mathrm{Pb}(\mathrm{II})$ using XAD-4 sorbent prior to atomic absorption spectroscopy. Int J Occup Saf Ergon 13:137-145

Singh AK, Banerjee TK (2008) Toxic effects of sodium arsenate on the skin epidermis of air breathing catfish, Clarias batrachus (L.). Vet Arhiv 78:73-88

Storelli MM (2008) Potential human health risk from metals ( $\mathrm{Hg}, \mathrm{Cd}$ and $\mathrm{Pb}$ ) and polychlorinated biphenyls (PCBs) via seafood consumption: estimation of target hazard quotients (THQs) and toxic equivalents (TEQs). Food Chem Toxicol 46:2782-2788

Usero J, Gonzalez-regalada E, Gracia I (1997) Trace metal in the bivalve molluscs Ruditapes decussates and Ruditapes philippinarium from the Atlantic coast of southern Spain (J). Environ Int 23:291-298

Vaseem H, Banerjee TK (2012) Phytoremediation of the toxic effluent generated during recovery of Precious metals from polymetallic sea nodules. Int J Phytoremediat 14:457-466

Vaseem H, Banerjee TK (2013) Biochemical alteration in the fish $(L$. rohita) tissues following exposure to the effluent generated 
during extraction of metals from polymetallic sea nodules. Clean Soil Air Water. doi:10.1002/clen.201200680

Vinodhini R, Narayanan M (2008) Bioaccumulation of heavy metals in organs of fresh water fish Cyprinus carpio (Common carp). Int J Environ Sci Tech 5:179-182

Wagner A, Boman J (2003) Biomonitoring of trace elements in muscle and liver tissue of freshwater fish. Spectrochim Acta B 58:2215-2226
Zyadah MA, Abdel-Bakey TC (2000) Toxicity and bioaccumulation of copper, zinc and cadmium in some aquatic organisms. Bull Environ Contam Toxicol 64:740-747 